\title{
Hypolipidemic Activity of Microwave-Dehydrated Mango (Mangifera indica L.) Powder in Mice Fed a Hypercholesterolemic Diet
}

\author{
Obed Osorio-Esquivel1,2, Vianney Cortés-Viguri1, Leticia Garduño-Siciliano ${ }^{3}$, \\ Alicia Ortiz-Moreno ${ }^{1}$, María Elena Sánchez-Pardo ${ }^{*}$ \\ ${ }^{1}$ Department of Biochemical Engineering, National School of Biological Sciences, National Polytechnic Institute, \\ Mexico City, Mexico \\ ${ }^{2}$ University of Chalcatongo, Avenida Universidad, Chalcatongo of Hidalgo, Mexico \\ ${ }^{3}$ Department of Physiology, National School of Biological Sciences, National Polytechnic Institute, \\ Mexico City, Mexico \\ Email: ${ }^{*}$ alimentoselena@hotmail.com
}

Received 4 June 2014; revised 20 July 2014; accepted 2 August 2014

Copyright (C) 2014 by authors and Scientific Research Publishing Inc.

This work is licensed under the Creative Commons Attribution International License (CC BY). http://creativecommons.org/licenses/by/4.0/

cc) (i) Open Access

\section{Abstract}

The effect of dietary supplementation with mango (Mangifera indica L.) powder obtained by microwave dehydration was studied in normal and hypercholesterolemic mice. The phenolic profiles in methanolic extracts and antioxidant activities were determined using high-performance liquid chromatography and DPPH (1,1-diphenyl-2-picrylhydrazyl) and ABTS (2,2'-azino-bis-3-ethylbenzothiazoline-6-sulphonic acid) assays, respectively. The total phenolic content of microwavedehydrated mango powder was $1451.7 \pm 26.7 \mu$ ggallic acid equivalents/g dry weight. The main phenolic compounds identified were gallic acid, epicatechin, ferulic acid, and catechin. The antioxidant activity was $14.6 \%$ higher in microwave-dehydrated mango powder than in conventional mango powder. Mice were fed a hypercholesterolemic diet ( $1 \mathrm{~g}$ cholesterol/100g over 7 days). The hypercholesterolemic mice whose diets were supplemented with microwave-dehydrated mango powder showed a significant decrease $(P \leq 0.05)$ in total serum cholesterol compared to the hypercholesterolemic mice and the mice fed with conventional dehydrated mango powder. We observed a significant increase $(P \leq 0.05)$ in HDL-c levels in the microwave-dehydrated mango powder group mice $(12.4 \pm 1.3 \mathrm{mmol} / \mathrm{L})$ compared to the hypercholesterolemic group $(8.6 \pm 1.4$ $\mathrm{mmol} / \mathrm{L})$ and the conventional-dehydrated mango powder group $(10.9 \pm 1.3 \mathrm{mmol} / \mathrm{L})$. The mice provided with microwave-dehydrated mango powder had significantly lower $(P \leq 0.05)$ levels of

*Corresponding author.

How to cite this paper: Osorio-Esquivel, O., Cortés-Viguri, V., Garduño-Siciliano, L., Ortiz-Moreno, A. and Sánchez-Pardo, M.E. (2014) Hypolipidemic Activity of Microwave-Dehydrated Mango (Mangifera indica L.) Powder in Mice Fed a Hypercholesterolemic Diet. J. Biomedical Science and Engineering, 7, 809-817. http://dx.doi.org/10.4236/ibise.2014.710080 
serum LDL-c (36.0\%) and total cholesterol (43.3\%) compared to the mice in hypercholesterolemic group. Notably, the atherogenic index was $72 \%$ lower in the microwave-dehydrated mango powder group compared to the hypercholesterolemic group. These results suggest that the biocompounds, such as polyphenols and dietary fiber, found in mango pulp might improve the lipid profile in mice fed a hypercholesterolemic diet.

\title{
Keywords
}

\author{
Hypolipidemic Activity, Microwave-Dehydrated Mango Powder, Hypercholesterolemic Diet, \\ Phenolic Profiles
}

\section{Introduction}

Mango (Mangifera indica L.) is one of the most important crops in the world and is cultivated in tropical and subtropical regions, this fruit is the fifth in importance within the worldwide production, in Mexico around eleven varieties are grown, which are intended for exportation, for internal consumption, as fresh fruit or for juice production [1]. Dehydration is recommended to prolong its shelf life, which is accomplished by elimination of water to a certain level where the quality reduction is negligible and the products can be stored with a shelf life of at least one year [2].

The use of microwave in the drying of products is widespread because it minimizes the deterioration of the quality and provides a heat distribution in the material quickly and efficiently. Thus a high quality product is obtained, it reduces the drying period and a power saving is achieved during the dehydration process [3]. Microwave energy is an excellent alternative for the processing of fruits and vegetables because it reduces the impact of elevated temperature and improves the retention of thermolabile compounds such as polyphenols, vitamins, carotenoids and other secondary metabolites [4]. Several studies have focused on evaluating the effect of the microwaves in the phytochemicals compounds in the fruits treated with this technology. For example, the heating of mandarin pulp with microwaves showed that phenolic compound is released from the cellular structures, increasing its content and the antioxidant capacity of the extracts, thus it was concluded that the microwave treatment can reasonably be considered to increase the antioxidant capacity of the fruit pulp. Microwave energy is an excellent alternative for the processing of fruits and vegetables because it reduces the impact of elevated temperature and improves the retention of thermolabile compounds such as polyphenols, vitamins, carotenoids and other secondary metabolites [5].

Mango fruit contains several phytocompounds, including polyphenols, carotenoids, and vitamins, which have several pharmacological properties [6]. Because mango possesses antioxidant properties, the phytochemicals in mango provide protection against oxidative damage. In addition to these benefits, the mango fruit has special sensory characteristics, including excellent flavor, attractive aroma, color, and delicious taste. Phenolic compounds enhance the stability of low-density lipoproteins (LDL) towards oxidation because of the conjugated ring structures and hydroxyl groups in these compounds. In addition, phenolic compounds have important antioxidant activities, such as the scavenging of superoxide anions, singlet oxygen molecules, and lipid peroxyl radicals and the stabilization of free radicals associated with oxidative processes by hydrogenation or complexation with the oxidizing species [7]. Considering that the use of microwaves for processing plant food products reduces processing time and enhances product quality [8] this study is focused on the hypolipidemic activity of mango powder obtained by microwave dehydration.

\section{Materials and Methods}

\subsection{Plant Material}

The Paradise variety of mango (Mangifera indica L.) was purchased at a local market in Mexico City. The fruits were washed and disinfected (Citrus $21^{\circledR} 5 \mathrm{~mL} / \mathrm{L}$ ), and the pulp was separated manually. The pulp was then dried using a microwave or by conventional methods. 


\subsection{Dehydration Methods}

\subsubsection{Microwave Treatment}

The dehydration process was performed in a microwave oven (SHARP R-530ES model with 1200 Watts of output, Crestwood, KY, USA). One hundred grams of mango pulp was distributed uniformly on a circular glass plate and microwaved at a power of 505.2 Watts for 9 minutes and 36 seconds. The microwave drying process was optimized by response surface methodology (RSM) [9] with a central composite experimental design generated using the Design-Expert 7.1.5 software (State-Ease Corporation, Minneapolis, USA). The resulting powder was called microwave-dehydrated mango powder (MMP).

\subsubsection{Conventional Treatment}

The conventionally dehydrated mango powder (CMP) was generated using a laboratory oven (Lindberg-Blue M, model VO914A, Southern California, USA) at $60^{\circ} \mathrm{C}$ for $24 \mathrm{~h}$; these conditions were used to obtain similar color and Aw parameters relative to the MMP.

\subsection{Extraction and Quantification of Total Phenolic Content (TPC)}

One gram of the dehydrated samples was mixed with $10 \mathrm{~mL}$ of $60 \%$ methanol for $30 \mathrm{~min}$ at $180 \mathrm{rpm}$ at room temperature. The mixture was centrifuged at $1000 \times \mathrm{g}$ for $10 \mathrm{~min}$ as in [10] and the extract was analyzed immediately. The TPC was calculated using the Folin-Ciocalteu method [11]. The absorbance of the extracts at 765 $\mathrm{nm}$ was measured using a spectrophotometer (Genesys 10uv scanning spectrophotometer, Thermo Spectronic, Rochester, NY, USA). A calibration curve was generated using gallic acid at concentrations ranging from 0 to $0.25 \mathrm{mg} / \mathrm{L}$, and the extracts were tested under similar conditions. All values were expressed as the means (mg of gallic acid equivalents (GAE) per g of dry extract) \pm SD of 3 replicates.

\subsubsection{HPLC-PDA Analysis of Phenolic Compounds}

Methanolic extracts were analyzed using a HPLC system (Agilent Technologies, 1260 INFINITY model, CA, USA) equipped with a photodiode-array detector (PDA) (Agilent Technologies, Seattle, USA) with a sample loop size of $200 \mu \mathrm{L}$. Chromatographic analysis was performed using an analytical C18 reversed phase column (ZORBAX SB C18, $150 \times 4.6 \mathrm{~mm}$ i.d., CA, USA) with a particle size of $5 \mu \mathrm{m}$. The mobile phase (A) contained $0.01 \%(\mathrm{v} / \mathrm{v})$ formic acid in water, and $100 \%$ methanol was used as the eluent $(\mathrm{B})$. The phenolics were separated at $30^{\circ} \mathrm{C}$ using a linear gradient of $15 \%$ to $30 \%$ B for $33 \mathrm{~min}$ at a flow rate of $1.0 \mathrm{~mL} / \mathrm{min}$. The phenolics were quantified at a wavelength of $280 \mathrm{~nm}$. Twenty microliters of the sample was injected. All the identified phenolics were quantified using external standards. The standards were dissolved in methanol/water $(80: 20, \mathrm{v} / \mathrm{v})$ to prepare the calibration curves.

\subsubsection{ABTS Free Radical Scavenging Assay}

The antioxidant activity of the powdered methanolic extracts on the free radical ABTS (2, 2'-azino-bis-3-ethylbenzothiazoline-6-sulphonic acid) was measured using the following method. Potassium persulfate (2.45 mM) was added to an ABTS solution (7 mM), and the resulting solution was incubated in the dark for $16 \mathrm{~h}$ at room temperature. The ABTS solution was diluted with ethanol and adjusted before analysis to obtain an absorbance of $0.7 \pm 0.02$ at $734 \mathrm{~nm}$. A $10 \mu \mathrm{L}$ aliquot of the methanolic extracts was added to $990 \mu \mathrm{L}$ of ABTS solution and mixed thoroughly. The absorbance at $734 \mathrm{~nm}$ was measured every minute for $7 \mathrm{~min}$, as in [12]. The results were expressed in $\mu \mathrm{MTrolox}$ Equivalents (TE) per gram of dry sample. All measurements were performed in triplicate, and the data are reported as the means $\pm \mathrm{SD}$.

\subsubsection{DPPH Radical Assay}

The antioxidant activity of the methanolic extracts on the free radical DPPH (1, 1-diphenyl-2-picrylhydrazyl) was measured using the method described by [13]. A $100 \mu \mathrm{L}$ aliquot of the methanolic extract (MMP and CMP samples) was mixed with $3.9 \mathrm{~mL}$ of a methanolic solution of DPPH. The reaction mixture was homogenized and incubated in the dark for 2 hours, and the absorbance at $515 \mathrm{~nm}$ was measured. The control sample contained methanol rather than the methanolic extracts. The antioxidant activity of the methanolic extracts was expressed as \% inhibition of DPPH \pm SD, which was calculated using the following equation: 


$$
\text { Antioxidant activity }(\%)=\frac{\text { Acontrol }- \text { Asample }}{\text { Acontrol }} \times 10
$$

\subsection{Total Dietary Fiber}

The total dietary fiber contents of the MMP and CMP samples were determined in triplicate using the 32-05 AOAC method [14]. The values are reported as the means \pm standard deviations (SD) g/100g dry weight (DW).

\subsection{Hypolipidemic Activity of Mango Powders}

\subsubsection{Animals}

Eight-week-old male CD-1 mice $(\mathrm{n}=32)$ with a mean weight of $28 \pm 2 \mathrm{~g}$ were used. The animals were purchased from the Propecua Company (Mexico City, Mexico) and were housed in metal cages in a well-ventilated room maintained at $23^{\circ} \mathrm{C}-25^{\circ} \mathrm{C}$ and $45 \% \pm 5 \%$ humidity with a $12 / 12$ light/dark cycle (light 8 AM-8 PM). For acclimatization, the mice were fed a commercial diet (Laboratory chow 5001 Lab Rodent Diet, PMI Nutrition International, Inc. Bienwood, MO, USA) and provided water ad libitum for one week. All procedures for animal treatment and experimentation were based on the Guide for the Care and Use of Laboratory Animals of the Mexican Council for Animal Care and approved by the Laboratory Animal Care Committee of the National School of Biological Science Ethics and Biosecurity Committee; all procedures and were conducted in compliance with the Official Mexican Standard NOM-062-ZOO-1999 of technical specifications for the production, care, and use of laboratory animals [15].

\subsubsection{Hypolipidemic Study}

Animals were randomly divided into four groups of eight mice. Over the six days of the experiment, the mice were provided mango powders or distilled water daily by gavage. Animals of the control group (Group A) were fed the standard diet and received distilled water $(10 \mathrm{~mL} / \mathrm{kg}$ BW). The Group B mice were fed a hypercholesterolemic diet ad libitum and received distilled water $(10 \mathrm{~mL} / \mathrm{kg}$ BW). The Group C mice received a hypercholesterolemic diet ad libitum to induce hypercholesterolemia and received CMP in a daily oral dose of $500 \mathrm{mg} / \mathrm{kg}$ BW. The Group D mice were given a hypercholesterolemic diet ad libitum to induce hypercholesterolemia and were provided MMP in a daily oral dose of $500 \mathrm{mg} / \mathrm{kg}$ BW. The hypercholesterolemic diet was prepared according to the diet formula shown in Table 1.

After six days of feeding, the mice were fasted overnight, and blood was collected through the retro-orbital sinus. The blood samples were centrifuged at $3000 \mathrm{~g}$ for $15 \mathrm{~min}$, and serum was collected to measure the lipid profile. The levels of total cholesterol (TC), triglycerides (TG), high-density lipoprotein cholesterol (HDL-C), and low-density lipoprotein cholesterol (LDL-C) were determined as described by [17]. The atherogenic index was calculated using Friedewald's equation $=(\mathrm{TC}-\mathrm{HDL}-\mathrm{c}) / \mathrm{HDL}-\mathrm{c}$.

\subsection{Statistical Analysis}

All physicochemical data were reported as the means of three replicates \pm standard deviations. Statistical analyses were conducted using Sigma Stat version 3.5 (Jandel, Corp., San Raphael, CA, USA). The hypolipidemic activity data were analyzed by one-way analysis of variance (ANOVA) and the Student-Newman-Keuls test,

Table 1. Composition of the hypercholesterolemic diet.

\begin{tabular}{cc}
\hline Ingredients & \% of total weight \\
\hline Laboratory chow 5001 & 53.3 \\
Sucrose & 30 \\
Casein & 10 \\
Butter milk & 5 \\
Cholesterol & 1 \\
Sodium chlorate & 0.5 \\
\hline
\end{tabular}

Source: [16]. 
and the data were reported as the means \pm standard errors. A P $\leq 0.05$ was considered statistically significant for hypolipidemic activity data.

\section{Results and Discussion}

\subsection{Total Phenolic Content}

Phenolic compounds and pigments are the main group of bioactive compounds that contribute to the antioxidant activity of vegetables and fruits [18]. Phenolic compounds help protect plants against ultraviolet light and participate in the defense against pathogenic microorganisms [19]. The total phenolic contents of the FMP (fresh mango pulp), MMP and CMP samples are shown in Table 2. The FMP sample contained the largest fraction of phenolic compounds, followed by the MMP and CMP samples. We observed that the TPC in methanolic extracts was higher in microwave treated pulp compared to conventionally treated pulp. The TPC (expressed as gallic acid equivalents) was $2279.5 \pm 10.03 \mu \mathrm{g} \mathrm{GAE} / \mathrm{g}$ (dry weight) for fresh mango pulp; after microwave treatment, the TPC decreased by approximately $36.3 \%$ compared to the MPF methanolic extract. However, the TPC in the CMP methanolic extract was $45.60 \%$ lower than the extract from the MPF sample. Different TPC values were reported for mango Haden variety $(48.40 \mathrm{mg} / 100 \mathrm{~g})$ but similar to those reported for the Ubá variety (208.7 mg/100g), as in [10].

The phenolic content of untreated mango cubes (variety Tommy Atkins) was $21.16 \mathrm{mg}$ GAE/100g fresh weight (FW) [20]. It is well known that higher phenolic contents can potentially contribute to improved antioxidant activity. The TPC of the Raspuri ripe mango (100.00 $\pm 1.9 \mathrm{mg} / 100 \mathrm{~g})$ measured by these authors is similar to our results, but it is higher than the TPC of the Badami ripe mango ( $54.67 \pm 1.5 \mathrm{mg} / 100 \mathrm{~g})$. The TPC in mango-peel powder is $96.2 \pm 1.4 \mathrm{mg}$ GAE$/ 100 \mathrm{~g}$, which is similar to the TPC in our MMP sample $(137.9 \pm 2.53 \mathrm{mg}$ GAE/100g) [18]. Consumption of phenolic compounds offers health benefits, including protection against cardiovascular diseases and cancer. Therefore, our results indicated that MMP and CMP are good sources of phenolic compounds.

\subsection{Phenolic Profile of the FMP, MMP, and CMP Samples}

Using HPLC-PDA analysis, four major peaks were detected at $280 \mathrm{~nm}$. These peaks were identified using external standards and by their spectral characteristics and retention times. The compounds that were identified are listed in Table 3. The main phenolic compound observed was gallic acid, followed by epicatechin, ferulic acid, and catechin. Flavonoids such as rutin, catechin, and quercetin are widespread in nature and might be powerful antioxidants [21].

Table 2. Total phenolic content (TPC) and antioxidant activity in (MPF) mango pulp fresh, (MMP) micro wave-dehydrated mango powder, (CMP) conventionally-dehydrated mango powder samples.

\begin{tabular}{cccc}
\hline \multirow{2}{*}{ Sample } & TPC $\mu \mathrm{g} \mathrm{GAE} / \mathrm{g}$ fresh weight. & \multicolumn{2}{c}{ Antioxidant activity } \\
\cline { 3 - 4 } & & ABTS $(\mu$ molTrolox $/ \mathrm{g} \mathrm{DW})$ & DPPH $(\mu$ molTrolox $/ \mathrm{g}$ DW $)$ \\
\hline MPF & $2279.5 \pm 10.03^{\mathrm{a}} \mu \mathrm{g} / \mathrm{g} \mathrm{DW}^{\mathrm{d}}(355.77 \pm 1.5 \mu \mathrm{g} / \mathrm{g} \mathrm{FW})$ & $11.9 \pm 0.4^{\mathrm{a}}$ & $7.6 \pm 0.1^{\mathrm{a}}$ \\
$\mathrm{MMP}$ & $1451.7 \pm 26.7^{\mathrm{b}} \mu \mathrm{g} / \mathrm{g} \mathrm{DW}^{\mathrm{d}}(1379.1 \pm 25.3 \mu \mathrm{g} / \mathrm{g} \mathrm{FW})$ & $11.3 \pm 0.3^{\mathrm{a}}$ & $1.5 \pm 0.1^{\mathrm{b}}$ \\
$\mathrm{CMP}$ & $1239.9 \pm 24.1^{\mathrm{c}} \mu \mathrm{g} / \mathrm{gDW}^{\mathrm{d}}(1145.56 \pm 24.2 \mu \mathrm{g} / \mathrm{g} \mathrm{FW})$ & $9.65 \pm 0.8^{\mathrm{b}}$ & $1.3 \pm 0.1^{\mathrm{c}}$ \\
\hline
\end{tabular}

Data expressed as mean \pm standard deviation; $\mathrm{n}=3$, analyzed by ANOVA. $\mathrm{P} \leq 0.05$.

Table 3. Phenolic profile of (MPF) mango pulp fresh, (MMP) microwave-dehydrated mango powder, and (CMP) conventionallydehydrated mango powder.

\begin{tabular}{cccccc}
\hline Compound name & Retention time $(\mathrm{min})$ & $\mathrm{UV}(\mathrm{nm})$ & $\mathrm{MPF}\left(\mu \mathrm{g} / \mathrm{g}^{\mathrm{a}}\right)$ & $\mathrm{MMP}\left(\mu \mathrm{g} / \mathrm{g}^{\mathrm{a}}\right)$ & $\mathrm{CMP}\left(\mu \mathrm{g} / \mathrm{g}^{\mathrm{a}}\right)$ \\
\hline Gallic acid & 3.21 & 280 & $2.9 \pm 0.01$ & $2.8 \pm 0.02$ & $2.2 \pm 0.01$ \\
Catechin & 8.12 & 280 & - & $0.01 \pm 0.001$ & $0.01 \pm 0.001$ \\
Epicatechin & 12.16 & 280 & $1.5 \pm 0.02$ & $0.1 \pm 0.005$ & $0.1 \pm 0.008$ \\
Ferulic acid & 17.56 & 280 & $0.06 \pm 0.001$ & $0.02 \pm 0.009$ & $0.2 \pm 0.008$ \\
\hline
\end{tabular}

${ }^{\mathrm{a}}$ Data expressed as mean \pm standard deviation; $\mathrm{n}=3$. 
The phenolic profile of mango pulp powders is important because these compounds have diverse biological effects, such as reduction of plasma lipid levels in the human body through the upregulation of LDL receptor expression, inhibition of hepatic lipid synthesis and lipoprotein secretion, and enhancement of cholesterol elimination through bile acids [22].

The presence of mangiferin and gallotannins in mango pulp [23]. Other reports have indicated that the major phenolics in mango are leucocyanidin, catechin, epicatechin, chlorogenic acid and quercetin [24]. However, [22] reported that gallic acid was the major polyphenolic in mangoes, followed by six hydrolyzable tannins, $\mathrm{p}-\mathrm{OH}-$ benzoic acid, m-coumaric acid, p-coumaric acid, and ferulic acid. Similar results were obtained by [21], who identified 20 polyphenols in mango puree after purification on a Sephadex column; these compounds included gallic acid, caffeic acid, protocatechuic acid, p-coumaric acid, mangiferin, quercetin 3-ara-glc (peltatoside), kaempferol (hexose), six quercetin derivatives, gallotannin, and others. The most abundant phenolics in mango cubes were gallic acid, p-hydroxybenzoic acid, p-coumaric acid, sinapic acid, quercetin, ellagic acid and catechin [24]. Recently, [25] reported the phenolic profiles and antioxidant properties of four mango cultivars: Tainong No. 1, Irwin, JinHwang and Keitt; among these cultivars, Tainong No. 1 had the highest number of phenolic compounds with a TPC of $22.18 \mathrm{mg} / 100 \mathrm{~g}$ fresh weight (FW).

\subsection{Antioxidant Activity on the ABTS and DPPH Radicals}

Antioxidant assays have been used to evaluate the antioxidant potential of bioactive compounds in several plant materials. Different antioxidant assays yield different results, and therefore, multiple methods are needed to obtain the most accurate antioxidant profile. The TEAC and DPPH assays provide reliable results [24] and we used the DPPH assay in this study. The observed antioxidant activities are listed in Table 2.

The free radical scavenging activity of all mango extracts was determined by the DPPH and ABTS methods. The free radical scavenging activity determined by the DPPH method varied from $1.3 \pm 0.1$ to $7.6 \pm 0.1$ $\mu$ moltrolox equivalents/g, and the values determined by ABTS ranged from $9.65 \pm 0.79$ to $11.97 \pm 0.36$ $\mu$ moltrolox TE/g (Table 2). Using the DPPH and ABTS methods, the antioxidant activities of the MPF and CMP samples were found to be higher and lower than the MMP sample, respectively. Our results are consistent with the values reported by [26] using the ABTS method, they observed a total antioxidant capacity of $13.2 \pm$ $0.3 \mu \mathrm{mol} \mathrm{TE} / \mathrm{g}$ in mango pulp from Brazil. In addition, they informed that after the dehydration process, the antioxidant capacity of the powders decreased significantly $(\mathrm{P}<0.05)$ in both powders. Antioxidant activity primarily involves the inactivation of singlet oxygen and the ability to react with free radicals; these properties are associated with beneficial effects such as protection against diseases related to oxidative stress [27]. In our study, there was no significant difference $(P>0.05)$ between the antioxidant capacities of fresh pulp and microwave-dehydrated pulp. This indicates that microwaves allow the maintenance of the high level of antioxidant polyphenols. There was significant difference $(\mathrm{P}<0.05)$ in the antioxidant properties of the powders obtained using the microwave-dehydration and conventional-dehydration processes. Notably, the antioxidant capacity observed using the DPPH assay was lower than that observed using the ABTS assay; this difference is because of the different mechanisms used by the antioxidants to inactivate the radicals tested. The ABTS assay indicated that microwave-dehydration of mango pulp did not cause the degradation of phenolic compounds.

The antioxidant activities of green and ripe mango (Keitt variety) evaluated and observed a significant correlation $\left(r^{2}=0.96\right)$ between the antioxidant activity and the total phenolic content of the fruits [23]. Phenolic compounds might contribute significantly to the antioxidant activity of fruit extracts. The antioxidant capacity of the mango fruit might be influenced by the presence of flavonoids and polyphenols [7]. Those compounds have redox properties that allow them to act as reducing agents, hydrogen donors, and singlet oxygen scavengers. We found that dehydration using microwaves preserves phenolic levels and antioxidant properties.

\subsection{Total Dietary Fiber}

Intake of dietary fiber offers health benefits, including protection against cardiovascular diseases, cancer, and other degenerative diseases. The total dietary fiber content in FMP was $1.74 \mathrm{~g} / 100 \mathrm{~g}$ using ripe fruit and 11.14 $\mathrm{g} / 100 \mathrm{~g}$ in the dehydrated mango. Results similar were obtained using the Keitt cultivar (1.6 and $1.4 \mathrm{~g} / 100 \mathrm{~g}$ of unripe and ripe fruit, respectively), which has a high pectin content [27]. This observation can be used to improve the nutritional contribution of foods, which associated with the prevention and/or treatment of diseases including colon cancer, high cholesterol, constipation, and diabetes [28]. Furthermore, intake of insoluble fibers 
promotes intestinal function by increasing viscosity in the small intestine, which enhances intestinal peristalsis, increases fecal bulk and reduces energy intake [29].

\subsection{Hypolipidemic Activities of Mango Powders}

The observed hypolipidemic activities of the mango powders (MMP and CMP) in mice are listed in Table 4. There were no differences in daily food consumption and average body weight gain between the treatment groups (data not shown). As expected, the group B mice had significantly higher $(\mathrm{P} \leq 0.05)$ TC and LDL-c levels (approximately 276\% and 358.5\%, respectively) compared to group A. The atherogenic index (AI) level was also significantly higher $(\mathrm{P} \leq 0.05)$ in the group B mice $(20.3 \pm 9.2)$ compared to group A. Serum HDL-c levels were lower in the group B mice (approximately $27.7 \%$ ) compared to group A.

The hypercholesterolemic diet caused significant modifications in triglycerides (TG) levels between groups A and B. The serum levels of LDL-c (36.0\%) and total cholesterol (TC) (43.3\%) were significantly lower (P $\leq$ 0.05 ) in the group supplemented with MMP powder compared to group B. Although the mice in groups D and C had decreased mean lipid levels, MMP powder reduced the lipid levels more than CMP powder. Notably, the serum HDL-c level was higher in the group D mice $(12.4 \pm 1.3 \mathrm{mmol} / \mathrm{L})$ compared to group B $(8.6 \pm 1.4$ $\mathrm{mmol} / \mathrm{L}$ ). Supplementation with MMP powder did not affect lipid parameters compared to group A (Table 3). Notably, we observed that the MMP powder increased the HDL level more than the CMP powder (Table 4), which indicates that MMP powder has a better effect on hypercholesterolemic mice. Furthermore, there was a marked decrease in the atherogenic index (72\%), caused by a lower LDL-c/HDL-c ratio in mice treated with MMP powder. The MMP powder might reduce lipid levels by an antioxidant mechanism. The main phytochemicals in mango powders are carotenoids and polyphenols. Carotenoids are efficient as Reactive Oxygen Species (ROS) quenchers, specifically against singlet oxygen and peroxyl radicals. The MMP powder might reduce lipid levels via an antioxidant mechanism. This hypothesis is supported by the analysis of antioxidant activity levels, which demonstrated that the MMP powder possessed higher free radical scavenging activity than the CMP powder. Mangiferin from the stem bark of Mangifera indica L. causes increased fecal elimination of bile acids and neutral sterols, which aids cholesterol reduction [30]. Flavonoids from the mango kernel elevated the activities of the glutathione peroxidase and glutathione reductase enzymes and the glutathione contents in the tissues of hypercholesterolemic rats, indicating an improved antioxidant mechanism [31]. Flavonoids in mango also inhibit lipid oxidation, a key step in atherosclerotic plaque formation [31]. Furthermore, MMP powder is a rich source of total dietary fiber, and this powder lowers the lipid level of hypercholesterolemic mice. Pectin is the main fiber present in mango (flesh and peel). Pectin is not hydrolyzed by the endogenous digestive enzymes in humans, and it is fermented by the colon microflora and recognized as a prebiotic. The biological activities of pectin include reduction of cholesterol, prevention of cancer, and regulation of blood glucose [7].

\section{Conclusion}

Microwave treatment did not affect the antioxidant properties of the nutraceutical components such as total polyphenols and dietary fiber in mango pulp. In addition, supplementation with microwaved-dehydrated mango powder attenuated the effect of hypercholesterolemic diet in mice; this effect was related to the high antioxidant activity of the powder.

Table 4. Serum parameters of mice treated with mango powders obtained by two dried methods.

\begin{tabular}{ccccccc}
\hline Groups & Mango powders Doses $(\mathrm{mg} / \mathrm{kg})$ & $\mathrm{TC}(\mathrm{mmol} / \mathrm{L})$ & $\mathrm{LDL}-\mathrm{C}(\mathrm{mmol} / \mathrm{L})$ & $\mathrm{HDL}-\mathrm{C}(\mathrm{mmol} / \mathrm{L})$ & $\mathrm{TG}(\mathrm{mmol} / \mathrm{L})$ & AI \\
\hline A & - & $45.2 \pm 2.4^{* *}$ & $32.40 \pm 1.7^{* *}$ & $11.90 \pm 1.2$ & $1.7 \pm 0.13^{* *}$ & $2.9 \pm 0.26^{* *}$ \\
B & - & $125.2 \pm 15.9^{*}$ & $116.2 \pm 17.3^{*}$ & $8.6 \pm 1.4$ & $0.89 \pm 0.09^{*}$ & $20.3 \pm 9.2$ \\
C & 500 & $81.9 \pm 6.6^{* * a}$ & $70.3 \pm 5.7^{* *}$ & $10.9 \pm 1.3$ & $1.2 \pm 0.16$ & $6.8 \pm 0.7^{* *}$ \\
D & 500 & $78.9 \pm 3.6^{* * b}$ & $65.9 \pm 3.3^{* *}$ & $12.4 \pm 1.3$ & $1.2 \pm 0.10$ & $5.7 \pm 0.6^{* *}$ \\
\hline
\end{tabular}

Data expressed as mean \pm standard error; $\mathrm{n}=8$, analyzed by ANOVA and Student-Newman-Keuls test. " $\mathrm{P} \leq 0.05$; significant difference with respect to the normocholesterolemic group. ${ }^{* *} \mathrm{P} \leq 0.05$; significant difference with respect to the hypercholesterolemic group. ${ }^{\text {a,b }} \mathrm{P} \leq$ 0.05; significant difference between treated groups with both mango powders. TC, Total cholesterol; LDL-c, Low-density Lipoprotein cholesterol; HDL-c, High-density lipoprotein cholesterol; TG, Triglycerides; AI, Atherogenic Index. A, control group; B, hypercholesterolemic group; C, conventional-dehydrated mango powder group; D, microwave-dehydrated mango powder group. 


\section{Acknowledgements}

Thisworkwassupportedbythe Instituto Politécnico Nacional (IPN) and Consejo Nacional de Ciencia y Tecnología scholarship, Secretaria de Investigación y Posgrado-IPN Proyect 20130135, and Comisión de Operación y Fomento de Actividades Académicas del IPN (COFAA-IPN). The authors declare that there is no conflict of interest.

\section{References}

[1] U.S. Department of Agriculture (USDA), Agricultural Research Service (2009) USDA National Nutrient Database for Standard Reference, Release 22. Nutrient Data Laboratory Home Page. http://www.ars.usda.gov/nutrientdata

[2] Hui, Y.H., Clary, C., Faid, M., Fasina, O., Noomhorn, A. and Welti-Chanes, J. (2007) Drying of Mango (Mangifera indica L.) and Mango Products. In: Food Drying Science and Technology: Microbiology, Chemistry, Applications, DEStech Publications I, Pennsylvania, 477-497.

[3] Ozkan, I.A., Akbudak, B. and Akbudak, N. (2007) Microwave Drying Characteristics of Spinach. Journal Food Engineering, 78, 577-583. http://dx.doi.org/10.1016/j.jfoodeng.2005.10.026

[4] Matsui, N.K., Gut, W.A.J., de Oliveira, P.V. and Tadini, C.C. (2008) Inactivation Kinetics of Polyphenol Oxidase and Peroxidase in Green Coconut Water by Microwave Processing. Journal Food Engineering, 88, 169-176. http://dx.doi.org/10.1016/j.jfoodeng.2008.02.003

[5] Hayat, K., Zhang, X., Farooq, U., Abbas, S., Xia, S., Jia, C., Zhong, F. and Zhang, J. (2010) Effect of Microwave Treatment on Phenolic Content and Antioxidant Activity of Citrus Mandarin Pomace. Food Chemistry, 123, 423-429. http://dx.doi.org/10.1016/j.foodchem.2010.04.060

[6] Pourahmad, J., Eskandari., M.R., Shakibaei., R. and Kamalinejad, M. (2010) A Search for Hepatoprotective Activity of Fruit Extract of Mangifera indica L. against Oxidative Stress Cytotoxicity. Plant Food for Human Nutrition, 65, 83-89.

[7] Ma, X., Wu, H., Liu, L., Yao, Q., Wang, S., Zhan, R., Xing, S. and Zhou, Y. (2011) Polyphenolic Compounds and Antioxidant Properties in Mango Fruits. Scientia Horticultura-Amsterdam, 129, 102-107. http://dx.doi.org/10.1016/j.scienta.2011.03.015

[8] Venkatesh, S.M. andRaghavan, V.S.G. (2004) An Overview of Microwave Processing and Dielectric Properties of Agri-Food Materials. Biosystems Engineering, 88, 1-18. http://dx.doi.org/10.1016/j.biosystemseng.2004.01.007

[9] Montgomery, D. (2010) Introducción al diseño de experimentos. Diseño y análisis de experimentos. Limusa-Wiley, México, 1, 170-211.

[10] Rocha-Ribeiro, S., Queiroz, J., Lopes-Ribeiro de Queiroz, M., Campos, F. and Pinheiro Sant'Ana, H. (2007) Antioxidant in Mango (Mangifera indica L.) Pulp. Plant Food for Human Nutrition, 62, 13-17. http://dx.doi.org/10.1007/s11130-006-0035-3

[11] Singleton, V.L., Orthofer, R. and Lamuela-Raventós, R.M. (1999) Analysis of Total Phenols and Other Oxidation Substrates and Antioxidants by Means of Folin-Ciocalteu Reagent. Methods in Enzymology, 299, 152-178. http://dx.doi.org/10.1016/S0076-6879(99)99017-1

[12] Pandarinathan, S. and Sivakumar, S. (2010) Studies on Biochemical Changes in Mangoes Due to Artificial Ripening. International Journal of Agricultural Sciences, 1, 3347-3355.

[13] Brand-Williams, W., Cuvelier, M.E. and Berset, C. (1995) Use of a Free Radical Method to Evaluate Antioxidant Activity. LWT-Food Science and Technology, 28, 25-30. http://dx.doi.org/10.1016/S0023-6438(95)80008-5

[14] AOAC (2005) Official Methods of Analysis, Vol. 1. Association of Official Analytic Chemist, Washington DC.

[15] Normas, D.G.N. (1999) Especificaciones Técnicas para la producción, cuidado y uso de los animales de laboratorio. Vol. NOM-062-ZOO-1999, Normas Mexicanas, México.

[16] Hisashi, M., Takeshi, C., Yasushi, K., Johji, Y., Tokunosuke, S., Hajime, F. and Hitoshi, K. (1986) Effects of Crude Drugs on Experimental Hypercholesterolemia. I. Tea and Its Active Principles. Journal of Ethnopharmacology, 17, 213-224. http://dx.doi.org/10.1016/0378-8741(86)90110-8

[17] Argüelles, N., Sánchez-Sandoval, E., Mendieta, A., Villa-Tanaca, L., Garduño-Siciliano, L., Jiménez, F., Cruz, M., Medina-Franco, J.L., Chamorro-Cevallos, G. and Tamariz, J. (2010) Design, Synthesis, and Docking of Highly Hypolipidemic Agents: Schizosaccharomyces pombe as a New Model for Evaluating $\alpha$-Asarone-Based HMG-CoA Reductase Inhibitors. Bioorganic \& Medicinal Chemistry, 18, 4238-4248. http://dx.doi.org/10.1016/j.bmc.2010.04.096

[18] Ajila, C.M., Naidu, K.A., Bhat, S.G. and Rao, U.J.S.P. (2007) Bioactive Compounds and Antioxidant Potential of Mango Peel Extract. Food Chemistry, 105, 982-988. http://dx.doi.org/10.1016/j.foodchem.2007.04.052

[19] Croft, K.D. (1998) The Chemistry and Biological Effects of Flavonoids and Phenolic Acids. Annals of the New York Academy of Sciences, 854, 435-442. 
[20] González-Aguilar, G.A., Villegas-Ochoa, M.A., Martínez-Téllez, M.A., Gardea, A.A. and Ayala-Zavala, J.F. (2007) Improving Antioxidant Capacity of Fresh-Cut Mangoes Treated with UV-C. Journal of Food Science, 72, S197-S202. http://dx.doi.org/10.1111/j.1750-3841.2007.00295.x

[21] Schieber, A., Ullrich, W. and Carle, R. (2000) Characterization of Polyphenols in Mango Puree Concentrates by HPLC with Diode Array and Mass Spectrometric Detection. Innovative Food Science \& Emerging Technologies, 1, 161-166. http://dx.doi.org/10.1016/S1466-8564(00)00015-1

[22] Kim, Y., Brencht, K.J. and Stephen, T.T. (2007) Antioxidant Phytochemical and Fruit Quality Changes in Mango (Mangifera indica L.) Following Hot Water Immersion and Controlled Atmosphere Storage. Food Chemistry, 105, 1327-1334. http://dx.doi.org/10.1016/j.foodchem.2007.03.050

[23] Mahattanatawee, K., Manthey, J.A., Luzio, G., Talcott, S.T., Goodner, K. and Baldwin, E.A. (2006) Total Antioxidant Activity and Fiber Content of Select Florida-Grown Tropical Fruits. Journal of Agricultural and Food Chemistry, 54, 7355-7363. http://dx.doi.org/10.1021/jf060566s

[24] Robles-Sánchez, M.R., Rojas-Graü, A.M., Odriozola-Serrano, I., González-Aguilar, G.A. and Martín-Belloso, O. (2009) Effect of Minimal Processing on Bioactive Compounds and Antioxidant Activity of Fresh-Cut 'Kent' Mango (Mangifera indica L.). Postharvest Biology and Technology, 51, 384-390. http://dx.doi.org/10.1016/j.postharvbio.2008.09.003

[25] Liu, F.X., Fu, S.F., Bi, X.F., Chen, F., Liao, X.J., Hu, X.S. and Wu, J.H. (2013) Physico-Chemical and Antioxidant Properties of Four Mango (Mangifera indica L.) Cultivars in China. Food Chemistry, 138, 396-405. http://dx.doi.org/10.1016/j.foodchem.2012.09.111

[26] Kuskoski, E.M., Asuero, A.G., Troncoso, A.M., Mancini-Filho, J. and Fett, R. (2005) Aplicación de diversos métodos químicos para determinar actividad antioxidante en pulpa de frutos. Ciencia y Tecnología de Alimentos, 25, 726-732. http://dx.doi.org/10.1590/S0101-20612005000400016

[27] Rocha-Ribeiro, M.S. and Schieber, A. (2010) Bioactive Compounds in Mango (Mangifera indica L.). In: Bioactive Food in Promoting Health: Fruits and Vegetables, Elsevier Publisher, Oxford, Chapter 34, 507-523.

[28] Ajila, C.M., Leelavathi, K. and Rao, U.J.S.P. (2008) Improvement of Dietary Fiber Content and Antioxidant Properties in Soft Dough Biscuits with the Incorporation of Mango Peel Powder. Journal of Cereal Science, 48, 319-326. http://dx.doi.org/10.1016/j.jcs.2007.10.001

[29] Galisteo, M.D.J. and Zarzuelo, A. (2008) Effects of Dietary Fibers on Disturbances Clustered in the Metabolic Syndrome. The Journal of Nutritional Biochemistry, 19, 71-84. http://dx.doi.org/10.1016/j.jnutbio.2007.02.009

[30] Prabhu, S., Mallika, J., Sabitha, K.E. and Shyamala-Devi, C.S. (2006) Effect of Mangiferin on Mitochondrial Energy Production in Experimentally Induced Myocardial Infracted Rats. Vascular Pharmacology, 44, 519-525. http://dx.doi.org/10.1016/j.vph.2006.03.012

[31] Anila, L. and Vijayalakshmi, R.N. (2002) Flavonoids from Emblica officinalis and Mangifera indica Effectiveness for Dyslipidemia. Journal of Ethnopharmacology, 79, 81-87. http://dx.doi.org/10.1016/S0378-8741(01)00361-0 
Scientific Research Publishing (SCIRP) is one of the largest Open Access journal publishers. It is currently publishing more than 200 open access, online, peer-reviewed journals covering a wide range of academic disciplines. SCIRP serves the worldwide academic communities and contributes to the progress and application of science with its publication.

Other selected journals from SCIRP are listed as below. Submit your manuscript to us via either submit@scirp.org or Online Submission Portal.
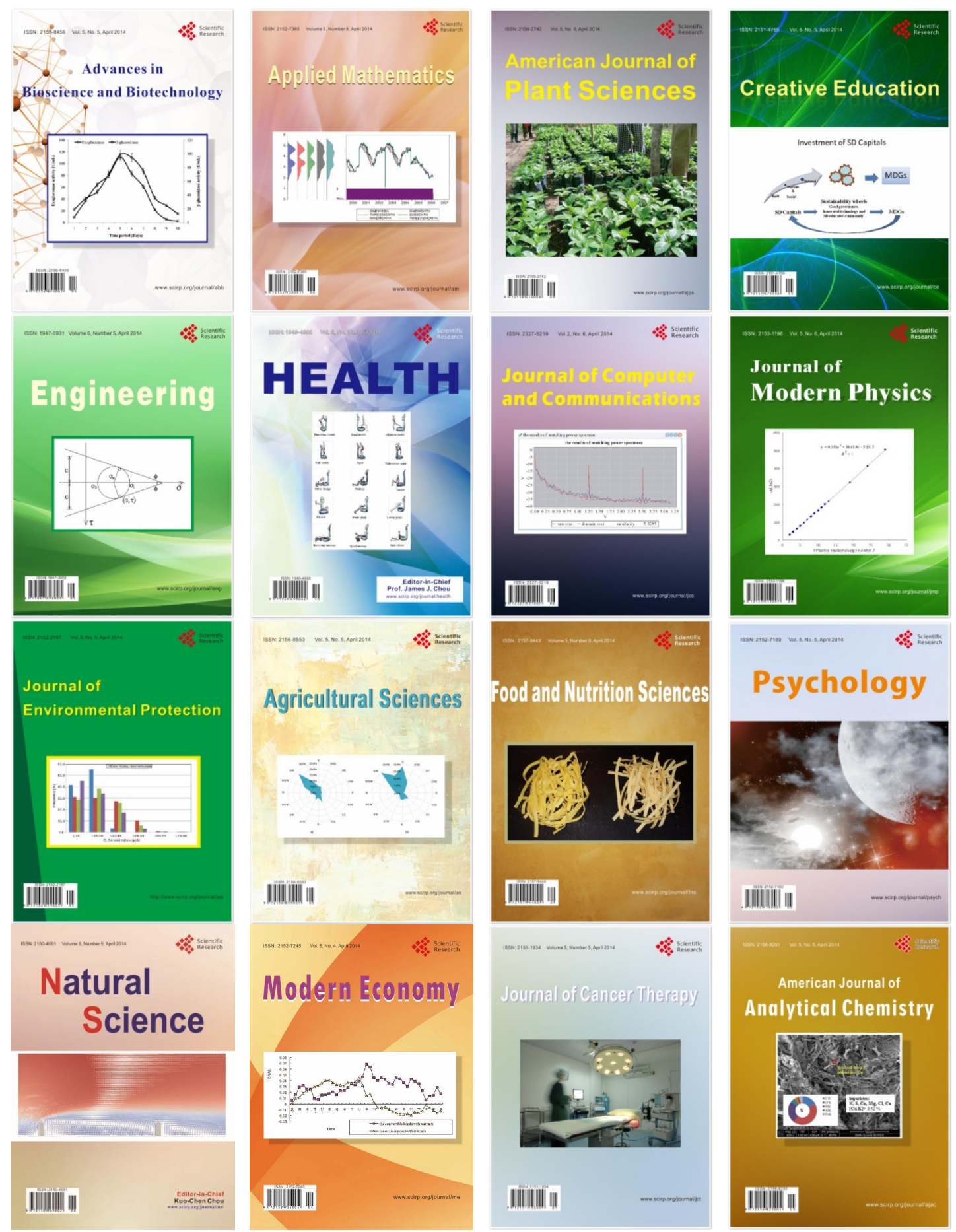